\title{
"DO POVO, PARA O POVO E PELO POVO": ORIGEM E EXERCÍCIO DA SOBERANIA POPULAR NA TEORIA POLÍTICA CONTEMPORÂNEA ${ }^{1}$
}

\author{
Gabriela Rodrigues da Guia Rosa ${ }^{\mathrm{a}}$ \\ ${ }^{a}$ Doutoranda em Ciência Política pela Universidade de São Paulo. São Paulo, SP, Brasil. \\ E-mail: gabrielargrosa@gmail.com \\ Orcid: 0000-0003-0913-3961 \\ http://dx.doi.org/10.1590/0102-019056/113
}

\section{Introdução}

Em 1863, Lincoln faz seu famoso discurso exaltando o poder "do povo, para o povo e pelo povo". Quem se perguntar sobre o significado da soberania popular certamente encontrará uma resposta que remete a algo desta célebre fala no cemitério de Gettysburg. Ou, para usar os termos de Daniel Lee (2016, p. 10), estamos diante de um conceito que é, ao mesmo tempo, uma "teoria regulatória do governo" ("para o povo") e uma "teoria constitutiva da autoridade pública" ("do povo"). Neste trabalho, contudo, nos interessa perceber como a soberania popular está associada a uma ficção que determina a origem e o exercício do poder político, partindo de uma revisão d'O Contrato Social (2006 [1762]), de Jean-Jacques Rousseau (1712-1778). Chamamos a atenção que há uma tensão inevitável entre esses dois aspectos da soberania popular, e que muitas vezes passa ao largo da

\footnotetext{
1 A autora agradece às(aos) pareceristas indicadas(os) pela Lua Nova pelos comentários atentos e relevantes a uma primeira versão deste texto, e à FAPESP pelo apoio na realização da pesquisa (nº do processo FAPESP: 2018/02426-9).
} 
reflexão de autoras e autores contemporâneos. Para dizer de outro modo, a familiaridade da ideia de povo como um sujeito político democrático encobre uma conexão nada trivial entre a soberania popular, o poder constituinte e a prática política constituída. Nesse sentido, pretendemos destacar que não há uma definição estática que nos permita apontar com precisão os limites e as qualidades daquilo que chamamos "povo". Tomando a clássica formulação de Rousseau como ponto de partida, investigaremos a distinção entre a origem e o exercício do poder político, apontando para a força da conexão entre a participação e a vontade geral, e para o seu impacto sobre o conceito de soberania popular no contexto democrático contemporâneo.

E não à toa escolhemos Rousseau, que foi aclamado como o grande teórico da participação direta por autoras como Hannah Pitkin (1967) e Carole Pateman (1970). Autores como Robert Dahl tratam o genebrino do 20 século XVIII como um defensor da democracia (2012, pp. 5-6), e mesmo do outro lado do espectro das teorias democráticas, Joseph Schumpeter associa a "doutrina clássica da democracia” à centralidade da vontade geral, para logo em seguida duvidar não apenas da sua existência, mas da sua validade como parâmetro para as democracias de seu tempo (2016, pp. 339-47). Ainda que não possa ser considerado propriamente um democrata, parece seguro afirmar que Rousseau é constantemente mobilizado como defensor de concepções da democracia que valorizam principalmente os aspectos não-eleitorais do (auto) governo. Nesses casos, a expectativa é que o povo se expresse para além do voto, e não apenas por meio de seus representantes. Não há dúvidas sobre a relevância da participação dos cidadãos na arquitetura rousseauniana do poder político legítimo. Ao mesmo tempo, há n’o Contrato Social uma concepção muito particular (e essencialmente política) de povo, capaz de unificar os mais diversos interesses por meio da vontade geral. 
A ênfase na participação e na generalidade da vontade coletiva são características elementares desse clássico conceito de soberania popular. De um lado, Rousseau nos diz que o povo reunido em assembleia é a autoridade política máxima (Rousseau, 2006, III, cap. 14, p. 111). De outro, apenas a vontade geral é capaz de realizar a finalidade do Estado, que é o bem comum (Rousseau, 2006, II, cap. 1, p. 33). A legitimidade das decisões políticas fica, então, tão atrelada ao sujeito detentor do poder (o povo) quanto ao seu conteúdo (a vontade geral). Nos dois casos, o poder ou a autoridade legítima dependem de algum tipo de unificação. Sem precisar defender o modelo rousseauniano de soberania do povo, ou mesmo atualizá-lo para contextos contemporâneos, nosso interesse pelo pensamento do genebrino resulta da sua notória influência - ainda hoje - no debate sobre a soberania popular constituinte e constituída (precisamente a diferença entre a origem e o exercício do poder político, tão bem descrita por Rousseau nos termos da diferença entre soberania e governo). Nesse mesmo sentido, este trabalho não se arrisca a desenvolver um estudo detalhado sobre a recepção dos escritos rousseaunianos pelas teóricas e teóricos políticos dos nossos tempos. Basta apenas que reconheçamos a importância da soberania do povo na conformação do ideal democrático desde o final do século XIX.

Nossa intenção é mostrar que certo paradigma rousseauniano da soberania popular ainda é relevante para pensar questões próprias do debate contemporâneo, e continua no horizonte da defesa normativa das democracias justamente porque associa a legitimidade da soberania do povo à participação direta na elaboração das leis. É verdade que o próprio Rousseau desconfiava da democracia, forma de governo "perfeita" e destinada a um "povo de deuses", mais que aos homens (Rousseau, 2006, III, cap. 4, p. 84). Por outro lado, sua insistência de que o poder legislativo deve ser confiado ao conjunto de cidadãos em seu papel de 
soberano, orientados pela vontade geral, foi amplamente mobilizada no sentido de justificar uma conexão direta entre a ideia contemporânea de democracia e certa versão da soberania popular. ${ }^{2}$

De acordo com Daniel Lee, esta é uma conexão típica da modernidade. A versão da soberania popular que confere ao povo poder de agência, e que se torna famosa a partir d'O Contrato Social, foi a referência de gerações de teóricas e teóricos democráticos que insistiam no valor da participação direta (Lee, 2016, p. 305). Ocorre que esta associação entre soberania popular e democracia não é tão imediata quanto pode parecer. Ao revisitar as formulações e disputas pré-iluministas em torno do conceito, Lee chama a atenção para a "narrativa convencional" da soberania popular como uma forma de resistir a um governante ou limitar suas ações como apenas uma parte da história (Lee, 2016, pp. 4-5). Não à toa, aliás, a solução dos constitucionalistas para lidar com 22 o poder absoluto do povo sobre a autoridade constituída é restringir sua ação aos momentos em que é preciso reparar ou transformar a ordem política vigente.

É que existe outra dimensão da soberania popular, lembra Lee, que se refere àquilo que constitui a autoridade pública legítima. Para ele, a doutrina da soberania popular foi elaborada, no contexto pré-moderno, como como uma "teoria constitutiva", que pretendia elucidar a constituição da autoridade pública na forma moderna do Estado unitário (Lee, 2016, pp. 9-10). Ela retrata a unificação de um agente coletivo não apenas porque a legitimidade do Estado

2 Bernard Manin, por exemplo, sugere que as ideias de Rousseau (e Sieyès) demonstram a força da demanda por unanimidade no pensamento democrático (1987, p. 383), ainda que sua intenção seja a de criticar o genebrino - que teria costurado a legitimidade política à uma noção de vontade geral que não admite contestação pública (1987, p. 383). Para Manin, como para Habermas (2020 [1988]), a legitimidade do poder político democrático não deriva da vontade, mas do processo de formação da vontade, ou seja, da deliberação - mas vale lembrar que as consequências dessa afirmação são radicalmente diferentes para cada um dos autores. 
moderno deva derivar-se do povo, mas porque a existência do Estado enquanto um ator coletivo (uma pessoa moral) depende inteiramente da unidade anterior do povo: "A existência do Estado, em suma, pressupõe a existência do povo" (Lee, 2016, p. 12, tradução nossa).

É possível pensar, então, que o propósito original da soberania do povo é mais negativo que positivo. Isto é, determina a quem ela não pertence, mas não oferece uma definição substantiva de seu detentor - não delimita quem faz parte do povo. Como uma ideia, uma abstração, a soberania popular funcionava perfeitamente bem contra os absolutismos e aparecia como um novo repositório - fictício e despersonalizado - da autoridade política. Ao mesmo tempo, era perfeitamente possível que um povo soberano indicasse um ditador como governante, à exemplo de Roma (Lee, 2016, pp. 318-319). Tornar à soberania popular, portanto, significou torná-la compatível com diversas formas de exercê-la, que não precisam ser necessariamente democráticas. Essa é a conclusão mais interessante do autor, que nos ajuda a entender por que gastamos, ainda hoje, tanta tinta e energia para definir as formas legítimas do exercício dessa autoridade. Dizer que o povo é soberano porque dele emana toda a autoridade quer dizer apenas que não estamos sujeitos, em última instância, às vontades de nenhum grupo ou indivíduo particular. Em outras palavras, mesmo um povo soberano, com plenos direitos de soberania, pode delegar o exercício da autoridade a um governo constituído: "ainda que a soberania tenha origem no povo e formalmente persista com eles como um direito, o exercício da soberania do povo poderia ser mediado e realizado por meios institucionais potencialmente não-democráticos” (Lee, 2016, p. 21, tradução nossa).

Há duas consequências importantes dessa revisão histórica e teórica do conceito de soberania popular que vale a pena destacar. A primeira delas, repetimos, é que soberania 
popular e democracia não são dois lados da mesma moeda, e carregam significados bastante distintos - ainda que sejam hoje muitas vezes sobrepostos. Mas essa sobreposição não é à toa: a vitória da democracia como retórica da legitimidade política - desbancando outras formas de governo - se deveu, em boa medida, à sua consolidação como uma agenda política que tem uma especificidade importante: cabe ao povo decidi-la (Dunn, 2019, p. 111). Mas essa é uma novidade do século XIX, já que mesmo os Pais Fundadores do que hoje chamamos democracia nos Estados Unidos preferiam governos populares republicanos (representativos), que ofereciam um sem-fim de vantagens quando comparados ao que entendiam ser a saída democrática. ${ }^{3}$

Outro ponto importante é que a coincidência entre democracia e soberania popular tende a enfatizar as formas de exercê-la politicamente. Ocorre que no contexto dos estados nacionais, o povo não governa diretamente, mas cria 24 condições e instituições por meio das quais outros possam agir em seu nome. Reforçamos que é esse o desassossego da teoria democrática, que segue em busca de maneiras pelas quais seja possível assegurar que prevaleçam o interesse comum e os princípios democráticos da liberdade, igualdade e autonomia. Mas há, como vimos, um outro momento da soberania do povo, que corresponde à origem da autoridade política. É essa forma de poder constituinte, esse "trunfo" ou capacidade extralegal de dissolver a autoridade constituída, que torna o povo de fato soberano.

Movidas, então, pela distinção entre a democracia e a soberania do povo, pretendemos neste texto apresentar alguns dos pontos importantes do conceito de soberania popular rousseauniana, de modo a lançar luz sobre

\footnotetext{
3 A versão original desse argumento pode ser lida no artigo famoso décimo d'O Federalista, escrito por Madison a propósito do debate público sobre a ratificação da nova constituição dos Estados Unidos entre 1787 e 1788 (Madison, Hamilton e Jay, 1993, pp. 133-139).
} 
o desafio de "permitir a livre expressão de interesses em conflito e ainda assim manter uma unidade mínima, sem a qual nenhuma sociedade pode existir" (Miguel, 2014, p. 13), ao mesmo tempo em que se mantém firme a distinção entre o poder constituinte do povo e a possibilidade de exercê-lo de maneira democrática.

\section{0 povo soberano de Rousseau: origem e exercício da autoridade política}

Quem é o povo e como ele manifesta a sua autoridade? Será que é possível separar a soberania do povo que origina o poder político da soberania que permite a este mesmo povo exercê-la? De fato, há um mal-estar relacionado à origem dos regimes democráticos, definidos a partir do ideal de "poder do povo" (Rosanvallon, 1998, pp. 8-9). As democracias engendram em sua definição um elemento concomitantemente político e sociológico, combinando um regime de autoridade específico (fundado na soberania popular) ao sujeito que está apto para exercer essa autoridade (o povo soberano). Paulina Ochoa Espejo (2011) dá uma definição interessante para este mal-estar identificado por Rosanvallon: trata-se do problema da "indeterminação da unificação popular". Para ela, as concepções tradicionais da soberania popular partem do seguinte paradoxo: apenas um povo unificado pode legitimar a fundação do Estado, mas não é possível apontar para nenhuma instância real da sua unificação.

É nesse ponto que a reflexão de Rousseau sobre a soberania popular parece oportuna. Rousseau se propôs a examinar "o ato pelo qual um povo é um povo" (2006, I, cap. 5, p. 19), que é o momento da fundação de uma sociedade política. Sua intenção é estabelecer a legitimidade do poder do povo enquanto agente coletivo e com um interesse comum, e por isso mesmo diferente da mera agregação de indivíduos. Também é preciso dar "movimento e vontade" 
ao pacto social que cria o povo, "Pois o ato primitivo pelo qual esse corpo se forma e se une, nada determina ainda daquilo que lhe cumpre fazer para conservar-se" (Rousseau, 2006, II, cap. 6, p. 45). A legitimidade do soberano na fundação da comunidade política é, então, diferente da legitimidade do povo no exercício de sua função de governante.

É verdade que o genebrino não foi o inventor da soberania popular, ${ }^{4}$ ainda que, como argumentamos, sua formulação tenha sido das mais influentes para as teorias políticas que pensam a democracia, pelo menos desde a Revolução Francesa. Sobre esse ponto, é digno de nota que esteja em um dos escritos de Robespierre, de $1794,{ }^{5}$ uma franca defesa da democracia como a forma de governo em que o povo é soberano. Segundo Dunn, isto bem poderia ser inspirado por certa leitura de Rousseau (2019, p. 95). De qualquer modo, estamos diante de uma novidade para o vocabulário político da época: a democracia aclamada por Robespierre era sinônimo de república, e em um sentido bastante específico de oposição à aristocracia (Dunn, 2109, p. 96). Como veremos a seguir, contudo, para Rousseau o governo legítimo é republicano, ou seja, é regido por leis (II, cap. 6, p. 48). Pode ser confiado aos muitos (democracia), a um pequeno número (aristocracia) ou mesmo estar nas mãos

${ }^{4}$ Em "Popular Sovereignty in Early Modern Constitutional Thought" (2016), Daniel Lee mostra como "princípios romanos da soberania popular" persistiram no pensamento de autores do fim do medievo, dos juristas no contexto das primeiras monarquias modernas, e até nas obras de Jean Bodin no século XVI - para Lee, "talvez o teórico mais importante da soberania popular" (2016, p. 22). Seguindo por outro caminho, que remonta à crise da soberania na Inglaterra do século XVII, os críticos parlamentaristas da monarquia sugerem que "na origem e de direito, o poder pertence ao povo" (Ostrensky, 2010, p. 154). Nesse mesmo contexto, e ainda mais enfaticamente, os chamados levellers redigiam panfletos sobre o "direito do povo ao autogoverno", afirmando que "nenhum homem jamais poderia consentir em alienar inteiramente o seu poder a quem quer que fosse, não importa se rei ou Parlamento" (Ostrensky, 2010, p. 158).

5 Trata-se do texto intitulado "Princípios de Moralidade Política que devem guiar a Convenção Nacional na Administração Interna da República” (Robespierre, 1794 apud Dunn, 2019, pp. 91-93). 
de um único magistrado (monarquia). É nesse sentido que o exercício do governo é diferente da soberania - essa sim, sempre confiada ao povo.

N'O Contrato Social há, pois, uma conexão explícita entre a soberania popular e a noção de vontade geral, uma das grandes novidades de Rousseau no bojo das discussões sobre a legitimidade do poder político de seu tempo até os dias atuais. ${ }^{6}$ A diferença entre "submeter uma multidão e reger uma sociedade" é precisamente marcada pelo estabelecimento de um corpo coletivo cujas decisões são baseadas em uma promessa recíproca conduzida pela vontade geral (Derathé, 2009, p. 330). O pacto, nesse sentido, oferece a cada um dos indivíduos "sua unidade, seu eu comum", e constitui a pessoa pública do povo, uma ficção que possui uma vontade que é geral e, portanto, diferente do interesse particular. A vontade geral determina o objeto e o conteúdo das leis que asseguram a liberdade dos cidadãos igualmente participantes do povo, ${ }^{7}$ e orienta as decisões políticas dos governantes e magistrados.

Em sua constituição, o poder político só é legítimo porque representa a unificação de todos e cada um "sob a suprema direção da vontade geral” (Rousseau, 2006, I, cap. 6, p. 22). O povo aí constituído é o coletivo dos cidadãos particulares, que é súdito porque sujeito à vontade geral, e soberano uma vez que a vontade geral é o seu

${ }^{6}$ Seguindo a interpretação de Robert Derathé, é possível pensar que a originalidade do contratualismo de Rousseau está diretamente relacionada à sua ênfase na instituição de uma autoridade política que preserve a liberdade - não a liberdade natural que experimentavam no Estado de Natureza, mas a liberdade (civil) de viver segundo a vontade geral, obedecendo apenas a si mesmo (2009, p. 335).

7 É importante lembrar que para Rousseau o pacto social é uma convenção na qual se baseia a autoridade legítima e que permite superar desigualdades naturais: "[...] em vez de destruir a igualdade natural, o pacto fundamental substitui, ao contrário, por uma igualdade moral e legítima aquilo que a natureza poderia trazer de desigualdade física entre os homens, e, podendo ser desiguais em força ou em talento, todos se tornam iguais por convenção e de direito" (ROUSSEAU, 2006, I, cap. 9, p. 30). 
interesse primeiro. ${ }^{8} \mathrm{E}$, se a vontade geral sempre visa ao bem comum, o vínculo social é o fundamento comum dos interesses particulares (Rousseau, 2006, II, cap. 1, p. 3). Essa generalidade também se expressa na reciprocidade do efeito das leis, como bem destaca Putterman: "[...] a razão é uma fonte de liberdade e justiça quando a reciprocidade das leis obriga cada indivíduo a se identificar apenas com o bem comum do todo" (2010, p. 11, tradução nossa). Dessa perspectiva, as leis que fundam uma sociedade bem constituída são gerais do ponto de vista lógico, já que resultam da convergência das vontades individuais, mas também são gerais porque são recíprocas - sujeitam a todos e cada um.

Como distinguir a vontade geral do interesse particular? É interessante como o autor salienta que se a vontade geral é sempre reta, disso não decorre que as deliberações do povo sejam igualmente boas. A vontade de todos diz respeito ao interesse privado, às vontades particulares. Para encontrar a vontade geral, faz-se uma soma das diferenças: “[...] se retiram dessas mesmas vontades os mais e os menos que se destroem mutuamente" (Rousseau, 2006, II, cap. 3, p. 37). Idealmente, todos alcançariam as mesmas conclusões acerca da vontade geral por serem todos igualmente racionais (Rousseau, 2006, II, cap. 3, pp. 37-8)..$^{9}$ Mas, à medida que se comunicam, os cidadãos estão sujeitos a influências externas que acabam por mediar a sua interpretação da vontade

\footnotetext{
8 Uma boa definição da vontade geral de Rousseau é a de Derathé: "A vontade geral é, sem dúvida, a vontade do corpo do povo inteiro, mas é também a vontade que cada associado tem, não enquanto indivíduo, mas enquanto membro da comunidade e membro do soberano" (2009, p. 341).

9 Convencido de que os homens em geral estão inebriados por suas paixões, Rousseau cria uma solução engenhosa para a instituição de um povo: a figura do legislador. Com uma "inteligência superior" (que conhece, mas não vive as paixões), este "homem extraordinário do Estado" não é nem magistrado, nem soberano, e a ele cabe o papel fundamental de redigir as leis de uma sociedade. Entretanto, para assegurar que a obra do legislador seja mantida perfeita, a ele não é dado nenhum outro poder legislativo ou executivo - suas leis não podem ser jamais alteradas, nem por ele, nem pelo povo (Rousseau, 2006, II, cap. 7).
} 
geral. O povo é facilmente confundido quando pertence a facções e associações, tende a defender publicamente interesses parciais, e é por isso que cada cidadão deve "opinar de acordo com seu próprio ponto de vista” (Rousseau, 2006, II, cap. 3, p. 38).

Ou seja, a vontade geral não representa o bem comum por ser majoritária, e sim porque expressa um "admirável acordo entre o interesse e a justiça” (Rousseau, 2006, II, cap. 4, p. 41). E a lei é a manifestação desse acordo, $o$ ato fundamental de soberania. Por isso, toda lei trata de matéria considerada geral, tão geral quanto a vontade que a constitui. Não trata do indivíduo ou de assuntos particulares e, nesse sentido, não pode ser feita senão pelo próprio povo em seu papel de soberano. ${ }^{10}$ Mais uma vez, vemos clara a relação entre a vontade (geral) e a lei fundamental. Nesse sentido, o poder executivo não pode pertencer ao povo como soberano: os atos do soberano são as leis fundamentais, que declaram a vontade geral. Aplicá-las, pelo contrário, depende de considerar a realidade particular (Putterman, 2010, p. 26). Para Rousseau, esse é o papel do governo, "encarregado da execução das leis e da manutenção da liberdade, tanto civil como política" do povo como súdito (Rousseau, 2006, III, cap. 1, p. 72).

A dualidade entre o poder legislativo e o poder executivo reproduz a tensão entre o soberano e o súdito, entre o poder constituinte o poder constituído. O governo - ou poder executivo - só existe por força do soberano, mas a sua

${ }^{10}$ Putterman (2010, p. 22) faz uma distinção entre o que ele identifica como as leis fundamentais, que são as expressões mais genuínas da vontade geral e instituídas pelo povo, e as leis particulares (ou decretos executivos) que têm por objeto questões e indivíduos particulares (e devem sempre estar de acordo com as leis fundamentais). Pode-se dizer, então, que o elemento central da legitimidade das leis fundamentais é a sua generalidade (Putterman, 2010, p. 26). Raquel Kritsch apresenta um entendimento semelhante ao afirmar que "Nem toda norma é lei: esta só pode referir-se a objetos gerais, tomando os súditos como um corpo e as ações como abstratas [...]. Mesmo o privilégio pode ser estabelecido legalmente, desde que seja descrito genericamente e não se destine a indivíduos identificáveis" (2011, p. 92). 
vontade nunca é tão geral quanto aquela representada nas leis fundamentais (porque não se legitima pela participação direta do soberano). Por isso mesmo, as ações do governo devem conformar-se à vontade geral. O problema da formulação das leis fundamentais segue, contudo, nebuloso. É preciso assegurar a participação de todos? Como tomar decisões coletivas nas assembleias?

Não basta que o povo reunido em assembleia tenha uma vez fixado a constituição do Estado, sancionando um corpo de leis; não basta que tenha estabelecido um governo perpétuo ou provido, de uma vez por todas, a eleição dos magistrados. Além das assembleias extraordinárias que casos imprevistos podem exigir, é necessário que haja fixas e periódicas, que por nada possam ser abolidas nem proteladas. (Rousseau, 2009, III, cap. 13, pp. 109-10)

A enfática recomendação de Rousseau traz à tona um dos temas mais famosos e sensíveis de sua obra: o papel da participação na legitimidade das decisões políticas. A reunião do povo em assembleia é o momento mais elementar da soberania, no qual "suspende-se o poder executivo e a pessoa do último cidadão é tão sagrada e inviolável quanto a do primeiro magistrado" (Rousseau, 2006, III, cap. 14, p. 111). A presença de todos os cidadãos dispensa a constituição de um governo (Rousseau, 2006, III, cap. 14, p. 111). Desfazem-se ali os corpos intermediários (executivos) que mantém a cidade cotidianamente viva e operante. Institui-se a autoridade soberana responsável por legislar, de quem emana toda a legitimidade da ordem institucional.

Como vemos, o genebrino é explícito em relação ao componente popular de sua noção de soberania. A participação direta dos cidadãos nas assembleias é imprescindível para a formulação de boas leis orientadas pela vontade geral. Esse é, então, o segundo elemento constitutivo da legitimidade 
das leis fundamentais: elas precisam ser ao mesmo tempo gerais em relação ao seu objeto - referem-se ao conjunto dos cidadãos - e gerais no procedimento - idealmente unânimes e definidas em assembleia. Por isso, não surpreende que Rousseau seja duro em sua crítica àqueles que se dizem representantes do povo. Para ele, a existência de representantes encarregados de determinar a vontade geral e as leis que dela decorrem abre margem para que o interesse particular prevaleça $^{11}$ e ameace a soberania do povo.

Vale a pena observar como esse conselho de Rousseau repercute. Hannah Arendt interpreta a vontade geral rousseauniana como um princípio unificador interno ao Estado, que inviabilizaria ou pelo menos tornaria desnecessária a troca de opiniões (Neves, 2017, pp. 82-83). Essa é, com efeito, a razão da crítica que a autora faz à ideia de soberania popular do genebrino em Sobre a Revolução, muito em virtude da sua preocupação com as consequências da instituição do poder do povo fora da esfera política, porque derivada da vontade (Arendt, 2020, p. 113). ${ }^{12}$

Saindo do polo das críticas, temos Hannah Pitkin e sua visão pessimista sobre o potencial democrático da representação. Em um texto de 2004, a autora caracteriza o genebrino como uma "voz democrática", por conectar diretamente a participação direta, pessoal e ativa dos cidadãos à liberdade e legitimidade das decisões políticas. Segundo ela, apesar de romântico e utópico para os dias de hoje, Rousseau estava

11 Rousseau, 2006, III, cap. 15, p. 114.

12 Neves (2017) chama a atenção que essa posição deriva de uma leitura específica de Rousseau, que para ele sobrevaloriza aspectos substantivos do contratualismo em detrimento dos elementos procedimentais da teoria do genebrino. É por isso que a Revolução Francesa descrita por Arendt "ganha mais ares de uma experiência precursora do totalitarismo do que um movimento de libertação do espírito humano" (2017, p. 86). Em que pese a validade das críticas, vale lembrar que anos depois Nadia Urbinati repete a mesma formulação ao sugerir que a soberania popular rousseauniana é excessivamente decisionista e ratificadora, e desconsidera o papel do juízo contra a vontade e a relação de mútua influência entre representantes e representados no período inter-eleitoral (2006, pp. 62-75; 223-228). 
certo ao afirmar que é impossível democratizar a representação porque os representantes não atuariam como agentes do povo, mas apesar dele (Pitkin, 2004, p. 339). A autora oferece uma solução para o problema: fortalecer formas de participação concretas e diretas no nível local, de modo que a experiência política compartilhada os permita revisar suas noções de interesse público e privado. Carole Pateman (2012) avança em sentido semelhante, defendendo que nem a deliberação substitui a participação direta. Ao analisar o orçamento participativo, a autora destaca exatamente que a atuação em "minipúblicos" pode melhorar a governança e reforçar a legitimidade das decisões políticas.

De volta aos escritos de Rousseau, vemos que distinção entre representantes e delegados indica precisamente o limite para a concessão de poderes políticos a outrem. Mais uma vez, é reforçada a importância da participação para assegurar a legitimidade do poder político instituído. É possível designar delegados, comissionados, responsáveis pelo exercício do poder executivo, o que não vale para a produção das leis, que, por serem declarações da vontade geral, devem manter-se nas mãos do povo. Ademais, essa é a maior garantia da liberdade - que as leis sejam produzidas pelo povo reunido em assembleia, e não pelos governantes.

Resgatar a soberania do povo de Rousseau importa, finalmente, porque motiva reflexões sobre o papel da unificação do povo e de uma ideia de bem comum, na justificação da legitimidade do poder político. A constituição das comunidades políticas depende de um contrato que, real ou hipoteticamente, implica o consentimento de todos com “[...] um compromisso recíproco do público com os particulares" (Rousseau, 2006, I, cap. 7, p. 23).${ }^{13}$ Estando unidos

${ }^{13}$ O pacto social se dá nos seguintes termos: "Cada um de nós põe em comum sua pessoa e todo seu poder sob a suprema direção da vontade geral; e recebemos, coletivamente, cada membro como parte indivisível do todo" (Rousseau, 2006, I, cap. 6, p. 22). 
em um "todo", o corpo coletivo dos cidadãos possui uma vontade geral e comum que representa o interesse coletivo. Aqui também a legitimidade do poder político consiste na "generalização" da vontade, em oposição à concorrência pública de interesses particulares. É o caso mesmo quando o autor reconhece os limites do exercício do poder político e do julgamento individual, que nem sempre visa ao bem comum. Uma decisão é mais legítima quanto maior o consenso, não porque seja maior a força do número, mas porque são maiores as chances de aproximar-se da vontade geral. O pacto social e a vontade geral manifestam o incontornável vínculo entre a legitimidade e certas formas de unificação, seja na constituição do corpo político ou na manutenção de sua virtude e vitalidade.

\section{0 legado unificador da soberania rousseauniana}

O modelo rousseauniano, que evoca as pequenas democracias participativas e orientadas para o bem comum, atravessou os séculos, as teorias da democracia e da soberania popular - para inclusive inspirar experiências democráticas contemporâneas. Paulina Ochoa Espejo (2011) destaca o impacto de pressupostos de unificação na teoria política e na própria ideia de poder constituinte, enquanto Pierre Rosanvallon $(2008,2011)$ ajuda a perceber traços dessa unificação e consenso nas democracias representativas. Rosanvallon (2008), então, explica por que esse "passado cívico idealizado" ainda representa algo de uma grande promessa não realizada das democracias contemporâneas. As primeiras palavras do autor sobre "a democracia em tempos de desconfiança" sugerem que apesar da persistência do ideal democrático, democracias reais vêm sendo criticadas em todo lugar - e esse talvez seja um dos grandes paradoxos políticos dos nossos tempos (Rosanvallon, 2008, p. 1).

Então, se encontramos diversos diagnósticos pessimistas em relação ao futuro das democracias representativas 
(Pateman 1970, 2012, Fraser 1990, Pitkin 1967, 2004, Espejo 2011, e mais recentemente Levitsky e Ziblatt, 2018, Runciman, 2019, Przeworski, 2020, para citar apenas alguns), haveria solução para comunidades políticas que desviaram tanto do suposto "modelo original" e acabaram traindo suas promessas originais de liberdade, igualdade e autonomia? Rosanvallon propõe uma abordagem interessante para o problema, que nos ajuda a pensar sobre os impactos dessas democracias representativas sobre o conceito de soberania popular.

Para entender melhor o lugar deste "modelo original" e lidar com as ambiguidades da representação democrática contemporânea, nosso caminho passa por entender de que maneira Rosanvallon identifica a persistência do "povo" e da vontade geral como fundamentos da legitimidade do poder político. Em Democratic Legitimacy: Impartiality, Reflexivity, Proximity (2011), o autor mostra que não é nada óbvia ou "natural" a coincidência entre a soberania popular e o princípio da maioria endossado pelo modelo eleitoral. "Um é um sujeito político comum, ou se você desejar, uma manifestação filosófica de um sujeito político, enquanto o outro é um procedimento pragmático de seleção". (Rosanvallon, 2011, pp. 1-2, tradução nossa). As democracias representativas sobrepõem um princípio de justificação e uma técnica de decisão, confundindo dois elementos de natureza bastante diversa. ${ }^{14} \mathrm{Um}$ problema que aumenta quando se procura justificar o resultado eleitoral com base em formulações que recuperam a vontade geral e a força da unanimidade: "[...] nós nos comportamos como se a maioria fosse o mesmo que o todo, como se o governo da maioria fosse um modo aceitável de impor

\footnotetext{
14 "A justificação do poder pelas urnas sempre repousou implicitamente na ideia de uma vontade geral e, então, em um povo que simbolicamente representa toda a sociedade" (Rosanvallon, 2011, p. 2, tradução nossa).
} 
demandas mais poderosas aos governados" (Rosanvallon, 2011, p. 2, tradução nossa).

Foi essa sobreposição entre procedimento e justificação, que combina sufrágio universal e governo das leis, o que permitiu que modelos representativos de governo fossem adotados como formas democráticas. Entretanto, Rosanvallon chama a atenção para o significado das eleições até pelo menos o século XIX: elas eram, antes de tudo, um "ritual de comunhão" em que se expressava a confiança da comunidade em suas lideranças (2011, pp. 20-21). Mais que tornar públicas divisões e discordâncias, a contagem dos votos era uma demonstração de unidade política. Vemos, portanto, que a unanimidade não é tanto uma questão numérica e mais uma "qualidade social", para usar as palavras do autor. De outro lado, o emprego do método eleitoral atesta a importância de alguma forma de participação desde as primeiras formas democráticas. O ideal da inclusão foi primeiro associado à busca por consensos, e só depois passou a refletir a diversidade de opiniões e preferências individuais.

Amarrar a regra da maioria a um ideal de unanimidade representou, então, um esforço teórico e político no sentido de estabelecer a legitimidade do poder político nos termos aqui chamados rousseaunianos. Isso se sustenta, segundo Rosanvallon, até a segunda metade do século XIX. O acirramento dos conflitos de classe reconfigura o voto como expressão da diferença e mecanismo de resolução de conflitos (Rosanvallon, 2011, p. 30). A crescente desconfiança de que os partidos políticos fossem capazes de defender interesses verdadeiramente coletivos torna importantes (e mais competitivos) os resultados eleitorais, deprimindo-se a força "ritual" e unificadora do processo. Não à toa, as lutas pelo sufrágio universal na Inglaterra e na França do período salientavam que o governo deveria satisfazer as necessidades da maioria (pobre e trabalhadora). Era preciso "ajustar" 
a representação para que fossem igualmente corrigidas as decisões sobre as políticas públicas.

O contexto do final do século XIX era de desconfiança em relação ao mecanismo eleitoral. Se as eleições ainda eram legalmente legítimas, sua autoridade moral estava permanentemente comprometida (Rosanvallon, 2011, p. 30). O século XX inaugura, então, uma nova forma de legitimidade associada às burocracias governamentais, que antes eram vistas como meros agentes do poder executivo na implementação das leis elaboradas pelos legisladores. $\mathrm{O}$ aumento drástico dos Estados demandava eficiência, e a perda de prestígio dos parlamentos refletia a desilusão sobre a capacidade de os representantes eleitos expressarem a vontade geral.

Essa atmosfera de desencanto abarca e incentiva a dissociação entre o elemento substantivo e o elemento procedimental da democracia. A regra da maioria valida o resultado eleitoral, mas já não assegura nenhum consenso político. Manin (2007) explica que isso acontece principalmente porque há uma marca aristocrática nas formas representativas de governo, que o autor chama de princípio da distinção. Ocorre que os indivíduos, no processo eleitoral, não são escolhidos por sua semelhança com os eleitores, mas principalmente por sua superioridade em relação a eles (Manin, 2007, p. 94). Nem mesmo as reformas democratizantes do século XIX e início do século XX foram capazes de retirar da representação o seu caráter aristocrático. A expansão do sufrágio e o fim da qualificação dos representantes a partir da renda mantiveram o hiato entre representantes e representados.

Importante frisar, sobretudo, que a articulação da democracia como uma forma e um ideal de governo não é imediata e nem desprovida de tensões, como já sugerem os escritos de Rousseau. Aventar a soberania do povo como origem e exercício da autoridade política legítima consolidou 
a busca de certa unanimidade ou consenso (a vontade geral) como um valor moral, social e político, ${ }^{15}$ mesmo em contextos tão heterogêneos e plurais como o das democracias modernas dos séculos XIX e XX.

A longa sobrevivência do paradigma rousseauniano da vontade (e da própria existência de uma formulação única do bem comum) demonstra a sua força mesmo diante de significativas transformações históricas, com consequências práticas e normativas para a democracia como a entendemos hoje. É porque estamos duvidosas da realização das promessas democráticas de igualdade, liberdade e autogoverno, e receosas da disposição dos governantes em comprometerem-se com o bem comum, que é tão importante investigar os dilemas constitutivos da soberania do povo. A sociedade da desconfiança generalizada, diagnosticada por Rosanvallon (2008), gesta novas formas de participação e legitimidade, e entendê-las depende de reconhecer os problemas impostos pelo ideal da unanimidade democrática.

Essa é a inquietação que move a crítica de Paulina Ochoa Espejo (2011) ao que ela chama "a indeterminação da unificação popular". A autora se propõe a pensar que os problemas na consolidação das democracias talvez devam menos a más realizações do ideal da soberania do povo que ao próprio projeto da soberania do povo como ele tradicionalmente se apresenta (Espejo, 2011, p. 29). Para ela, entender "quem é o povo" é um dos problemas centrais da teoria política contemporânea, e que não vem sendo apropriadamente endereçado.

Ao longo do seu livro The time of popular sovereignty: process and the democratic state, Espejo argumenta que a legitimidade

\footnotetext{
15 "Regimes democráticos eventualmente adotaram o princípio do governo da maioria como uma necessidade prática procedimental, uma vez que a unanimidade numérica era impossível de ser alcançada. Mas ao mesmo tempo continuaram balançados por essa antiga ideia de unanimidade substantiva. Unanimidade substantiva é um conceito menos reducionista que unanimidade numérica” (Rosanvallon, 2011, p. 17, tradução nossa, ênfase no original).
} 
da soberania popular é construída sob a suposição da unificação popular (Espejo, 2011, p. 2). Mas por que essa tese segue apelativa para o público e até para os filósofos políticos de hoje? Em poucas palavras, diz Espejo, porque há uma suposição implícita de que, em um Estado "bom e justo", para usar os termos da autora, deve existir algum princípio que harmoniza todas as vontades por meio da razão. A legitimidade depende dessa coincidência entre vontade e razão, ou seja, de um consenso que é raro em pequenos grupos e impraticável nas grandes sociedades. Daí sugerir, pois, que a força da soberania popular não advém da unificação prática, mas de uma promessa de unidade essencialmente hipotética.

Assentar a legitimidade do poder do povo em uma hipótese de unificação é a única maneira de protegê-la dos abusos dos governantes. Se, como vimos com Rousseau, o povo não pode estar errado, então qualquer desvio da vontade geral resulta da "má aplicação" do conceito, e não de sua própria definição (Espejo, 2011, p. 5). Nesse sentido, encontrar as decisões que o povo tomaria caso fosse unificado bastaria para descobrir qual a melhor decisão, a mais legítima. ${ }^{16}$ Ocorre que, se não for possível estabelecer que os indivíduos de fato consentiriam, a legitimidade do Estado fica em risco. É por isso que as teorias da soberania popular apontam para a unidade no futuro ou no passado, mas não podem demonstrar essa unificação no presente (Espejo, 2011, p. 6).

Estamos aqui justamente às voltas com o problema de "quem é o povo", isto é, como distingui-lo da multidão desordenada ou de uma facção usurpadora. Ao lidar com um conceito político de povo - e não abordagens com

\footnotetext{
${ }^{16}$ Uma visão tão hipotética sobre a soberania popular também precisa supor que qualquer desacordo sobre os princípios de unificação ocorre apenas porque não se alcançaram as condições ideais para o consenso. Nesse caso é preciso afirmar também que não deve haver boas razões para discordar com tais princípios, caso se estabeleçam essas condições - que podem ser, por exemplo, o acesso à educação e ao desenvolvimento moral, ou mesmo o total acesso à informação antes da deliberação (Espejo, 2011, p. 6).
} 
ênfase em vínculos familiares ou culturais, noções que destacam elementos sociológicos (a ideia de que o povo são os pobres, por exemplo), ou exclusivamente territoriais - precisamos enfrentar o desafio de circunscrever uma comunidade política de maneira democrática. Não é trivial declarar que o povo é uma coleção de indivíduos que se reúnem voluntariamente com o propósito de organizar instituições de governo em determinado território, indivíduos que concordam com princípios que promovam a liberdade e a igualdade (Espejo, 2011, p. 37-8). Para a autora, esse é o corolário da unificação implícita na definição do povo nas democracias liberais modernas.

Ressurge, portanto, a dificuldade de estabelecer princípios democráticos que sejam anteriores e externos ao próprio povo, apresentada por Rousseau como o impasse em fazer com que os cidadãos sejam antes das leis aquilo que deveriam tornar-se por meio delas (Rousseau, 2006, p. 52). Espejo traduz a circularidade entre as boas leis e os bons cidadãos no paradoxo da autoconstituição do povo, que constantemente recai em um "círculo vicioso" entre os cidadãos e as instituições, a partir do qual é impossível definir o povo de maneira democrática. ${ }^{17}$

Este embaraço se resolve, para Rousseau, com o apelo ao legislador e à vontade geral, sempre justa e sempre reta. Ou, no mundo contemporâneo, pela suposição de uma espécie de consenso que nunca se realiza na prática - são as teorias mecânicas ou teleológicas da justificação da legitimidade do poder político do povo. Espejo utiliza essa nomenclatura para esclarecer as suposições implícitas a essas duas formas de unificação popular, destacando o conceito de

\footnotetext{
17 "Não se pode determinar, por meio do voto, quem pertencerá ao demos que vai votar sobre essa mesma questão. Mas se a escolha do critério de exclusão não será ela própria feita de modo democrático, então enfrentamos outro problema [...]. A não ser que o povo já esteja lá, não há como criar um povo democrático de maneira legítima" (Espejo, 2011, p. 42, tradução nossa).
} 
povo que subjaz a cada uma delas. Visões mecânicas recorrem a mecanismos (constitucionais e eleitorais) para indicar quais indivíduos podem participar das decisões coletivas, e como todos se mantêm unidos. "[...] há uma concepção mecânica de povo quando se pensa nas causas que juntam as pessoas" (Espejo, 2011, p. 68, tradução nossa). Segundo essa concepção da justificação da legitimidade do poder político, o povo se define pela maneira como se organiza coletivamente, pelas causas que o tornam povo. Ganham espaço debates sobre arranjos constitucionais e procedimentos eleitorais mais inclusivos e participativos, mas resta impalpável uma forma original de unificação, que ocorre em algum momento do passado ou do futuro e nunca se materializa uma vez que não há nenhum mecanismo perfeito de agregação das vontades.

Concepções teleológicas, por sua vez, frisam o objetivo do consenso, precisando o ponto de chegada comum para 40 então determinar a composição do povo. Como não é possível apontar para um momento de unificação do povo na história, a intenção é fazê-lo democrático a partir de ideais e princípios. "[...] o povo pode ser definido por sua tendência a se tornar o que deveria ser" (Espejo, 2011, p. 71, tradução nossa). Isto é, tendo em vista um propósito comum (liberdade, igualdade e autodeterminação coletiva), os indivíduos se esforçariam para alcançá-lo da melhor maneira. Nesse caso, deve-se supor que haja unanimidade sobre o projeto e os objetivos de uma sociedade democrática.

Espejo critica as duas concepções pelo mesmo motivo: o requisito da unificação em algum momento no tempo é o que fundamentaria a legitimidade do Estado democrático. Por isso, a autora considera as duas concepções deterministas - a existência das instituições se justifica pelo estabelecimento de objetivos ou pela escolha de um mecanismo para alcançá-los (Espejo, 2011, p. 72). Nas concepções teleológicas, o principal problema está em definir as formas pelas quais se 
deve, então, perseguir o ideal da democracia. A resposta para essa pergunta passa por resgatar algo como a vontade geral e reafirmar que o interesse individual de cada um coincide com o melhor interesse coletivo. Nesse caso, a vontade geral representa o objetivo e a condição para o estabelecimento de uma sociedade democrática, e a realização da soberania popular precisa ser aceita como uma meta legítima.

As concepções mecânicas, por sua vez, são deterministas porque confiam em mecanismos para explicar uma tendência natural à unificação. $O$ foco na causalidade entre os procedimentos e os ideais democráticos transforma contrato social na busca estratégica pelo auto interesse, e essa é a conexão entre as ações individuais e a vontade geral (Espejo, 2011, p. 78). O indivíduo racional é aquele que contribui para o bem público à medida que percebe as vantagens disso para si mesmo - e não necessariamente motivado por um ideal exterior. Ao final, espera-se que este equilíbrio entre o público e o privado justifique, ao mesmo tempo, as instituições do Estado e as fronteiras do povo.

O problema, então, é que legitimar a soberania popular a partir de "imagens do passado" significa nomear um momento fundador, instaurando o processo democrático a partir de referências cristalizadas. Assim, mesmo que as mudanças nas práticas e no povo possam ser incorporadas em um fluxo de democratização, é preciso estabilizar em uma narrativa histórica o momento de acordo universal sobre princípios - uma assembleia constituinte, por exemplo. Sofia Näsström (2007) considera esta uma maneira de escapar do problema da legitimidade do povo. Desse ponto de vista, a instituição de uma comunidade política é mais um fato histórico que um problema democrático, restando obliterada a conexão (ou o vácuo) entre o momento fundacional e a justificação da sua legitimidade.

Falar de visões do futuro, por outro lado, sugere que a legitimidade da soberania do povo está estreitamente 
ligada ao consenso sobre ideais de autonomia coletiva, liberdade e igualdade. De acordo com Näsström, a lacuna entre as leis e o governo, entre a igualdade e a autoridade, acaba por ser substituída pela noção de vontade geral, que estabelece um consentimento hipotético (2007, pp. 637-8). A expectativa de um acordo idealmente unânime é localizada no futuro exatamente para que se legitimem no presente as instituições que oferecem a possibilidade de alcançar coletivamente os ideais supostamente compartilhados por todos.

As análises de Rosanvallon e Espejo explicitam as tensões inevitáveis do conceito de soberania popular, lançando luz sobre marcas de unificação que encontramos também na formulação rousseauniana. Essa necessidade de unificação da vontade sob um princípio comum (e muitas vezes racional) determinou os significados de instituições e procedimentos intimamente relacionados com a prática democrática, como a regra da maioria, a eleição, a burocracia administrativa e o serviço público. Rousseau desvinculou a vontade geral e o interesse privado, para então tornar a vontade geral fundamentalmente incontroversa - o bem comum é mais que a agregação de vontades, é aquilo que resta quando são eliminadas todas as diferenças. Em boa medida essa é a suposição que sustenta as "imagens do passado" e as "visões do futuro" que temos das democracias, e delas decorrem uma legitimidade ancorada em um pretenso consenso (histórico ou hipotético).

A força unificadora dessa concepção de soberania popular é a mesma de suas contradições. Não há nenhuma solução fácil para o dilema entre a vontade e a opinião, a razão e o julgamento, a parte e o todo, o privado e o público. Todas essas são traduções diferentes para a dupla-indeterminação democrática a que se refere Rosanvallon, e que foram primeiro explicitadas por Rousseau. Como se tentou demonstrar, a legitimidade do poder político do povo tem 
sido intimamente associada a uma concepção de povo unificadora - que é mais questionada quanto mais se valoriza a particularidade, a experiência, o tempo e o possível papel potencialmente democrático do conflito.

\section{Aspectos democráticos da soberania popular}

A necessidade de unificação que conecta a origem e o exercício da autoridade política do povo no modelo rousseauniano é a característica da soberania popular que mais incomoda Espejo, Rosanvallon e tantos outros teóricos. A seu modo, ambos se perguntam como é possível ao povo ser súdito e, também, soberano? Vimos que a saída encontrada pelo genebrino é bastante demandante. Prevê a participação de todos os cidadãos nas assembleias que determinam as leis fundamentais, e a supervisão constante da atuação dos governantes por eles indicados. Rousseau veta a possibilidade de se conceder a outrem o direito de exercer o poder político em seu nome exatamente para assegurar que a generalidade que constitui esse poder seja reposta em seu exercício. Os interesses particulares configuram, portanto, um risco da maior magnitude (Rousseau, 2006, III, cap. 15, p. 113).

Encontramos na teoria democrática contemporânea o mesmo receio. Nesse sentido, o mesmo Rosanvallon (2008, 2011) aponta para as mudanças na ideia de povo a partir dos desafios das democracias contemporâneas, sublinhando que o povo não se define nem pela unanimidade e nem pela maioria. A legitimidade dos governos democráticos depende em boa medida da valorização de mecanismos indiretos de exercício da soberania, que envolvem por exemplo a participação direta na esfera local, a possibilidade de acompanhar os trabalhos dos representantes, a chance de exercer pressão por meio de manifestações. A contrademocracia de Rosanvallon representa esse esforço de pulverizar a vontade geral e multiplicar os canais de participação. Se a história das democracias modernas se caracteriza pela descrença na 
possibilidade da realização de um ideal, então a manifestação dessa desconfiança é um elemento constitutivo desse sistema político (Rosanvallon, 2008, p.5).

A desconfiança complementa o elemento estritamente eleitoral do projeto democrático. Daí a sugestão de que o poder político é composto de um elemento episódico e procedimental, e outro permanente e substantivo. Essas são, com efeito, as duas maneiras pelas quais é possível ao povo exercer o poder soberano - ou por meio do voto, ou por meio de mecanismos indiretos de controle que aumentam o poder de influência da sociedade nas decisões governamentais. Eis que surge uma nova forma de soberania, indireta, que se manifesta por meio da ação do povo como vigia ("watchdog"), como detentor do poder de veto e como juiz.

Essas novas formas de participação política não se encaixam nem nos cânones da representação, e nem da participação direta: na verdade, surgiram da distância cada vez maior entre as instituições e a sociedade. Mais ainda, foram os governos representativos que consolidaram a diferença entre governar (agir) e controlar, e a expansão dos poderes de controle aspira alguma compensação para os limites da participação direta (Rosanvallon, 2008, p. 80). Nesse sentido, entendemos que as reconsiderações sobre o conceito de soberania popular se deram muito em virtude dos limites para a unificação do povo, e resultaram em propostas que aumentam ou valorizam formas indiretas do exercício do poder político. A partir de um diagnóstico que reconhece os limites democráticos do modelo representativo tradicional, parece ser possível alargar a atividade do soberano para além do momento eleitoral, dando ênfase aos conflitos que permeiam o processo de formação de consensos dentro de uma sociedade.

Nadia Urbinati (2006) também se depara com a necessidade de repensar as bases da legitimidade do poder político hoje. A autora acredita que a deliberação promovida pelo 
modelo representativo é a chave para repensar o conceito de soberania popular. Nesse sentido, sugere um conceito de soberania democrática que supera a política da presença com uma política das ideias. Argumenta que a representação - e não meramente um governo representativo - é perfeitamente compatível com a democracia e, mais ainda, pode torná-la mais democrática. Do trabalho de Urbinati, Representative Democracy: Principles and Genealogy (2006), interessa principalmente que sua genealogia da representação democrática culmina na revisão do conceito de soberania popular de Rousseau.

Uma teoria democrática da democracia representativa implica uma revisão do conceito moderno de soberania popular, que desafia o monopólio da vontade na definição e na prática da liberdade política. Ela marca o fim de uma política do sim ou não, e o começo da política como uma arena aberta para opiniões contestáveis e decisões que sempre podem ser revisadas. Isso amplifica o significado da própria presença política porque faz da voz a sua manifestação mais ativa e consonante, e o juízo sobre leis e políticas justas e injustas o seu conteúdo. (Urbinati, 2006, p. 224, tradução nossa, ênfase no original)

Desafiar o monopólio da vontade como conteúdo fundamental da soberania popular significa abandonar o modelo rousseauniano, que Urbinati caracteriza como voluntarista e excessivamente decisionista. Esse é, com efeito, o ponto de partida da autora, que procura mostrar como a clássica proposta de soberania popular é pouco democrática porque admite que os cidadãos participem apenas na decisão final, e não na formulação ou na deliberação acerca das leis. Defende, então, que seja possível construir por meio da representação uma circularidade comunicativa entre representantes e representados, decisões e opiniões, Estado 
e sociedade. A representação formula-se como um processo que articula a política da presença à política das ideias, incorporando à soberania da vontade a noção de julgamento: o ato de autorização (momento chave da democracia direta ou eleitoral) é complementado por um processo que precisa se expandir ao longo do tempo. Ao contrário do que vê na proposta de Rousseau, Urbinati pretende que seja possível participar, de maneira indireta, em todo o processo democrático de decisão, que envolve uma multiplicidade de pontos de vista passíveis de mudança por meio do debate continuado - seja na sociedade civil ou nas esferas formais de representação.

\section{O tempo da soberania e o lugar do povo}

Do ponto de vista do exercício, portanto, a soberania popular se tornou democrática com o reconhecimento da legitimidade de suas formas indiretas de participação. Isso não significa que a participação eleitoral seja menos importante, mas apenas que ela é insuficiente. Também não pretendemos sugerir que estamos, por isso, completamente apartados da sugestão rousseauniana de participação direta. Vimos como Rousseau foi um teórico bastante comprometido em assegurar que o povo fosse, ele mesmo, capaz de exercer o poder político. Que ele tenha sugerido um modelo assembleista, adequado ao seu contexto, nos parece menos importante do que as muitas recomendações do autor para evitar que o interesse privado prevalecesse em detrimento do bem comum.

Interessa mais outra diferença entre a proposta do genebrino e a soberania popular democrática de hoje: a sua relação com o tempo. Para Putterman, a soberania de Rousseau é sempre um ato no tempo presente: não existe no tempo e nem ao longo do tempo. O povo soberano é constituído no momento da assembleia, e o conteúdo da vontade não pode ser determinado para o futuro, mas apenas para 
o presente (Rousseau, 2006, II, cap. 2, p. 35). É por isso que o povo volta a se reunir e pode, a cada assembleia, revogar todas as leis vigentes (e os magistrados responsáveis por sua execução). Esse exercício apenas momentâneo da soberania incomoda os teóricos democráticos porque sociedades complexas precisam de meios mais poderosos para lidar com o conflito - precisam, afinal de contas, de estabilidade. A produção de consensos imaginada por Rousseau se torna muito mais difícil quando não se pode recorrer à vontade geral, algo capaz de unir a todos.

De certo modo, as formas indiretas do exercício da soberania popular foram capazes de incorporar o tempo em seu significado fundamental. A legitimidade das decisões políticas nas democracias contemporâneas cada vez mais depende dos espaços institucionais e não institucionais de debate, que podem inclusive questionar e ressignificar uma decisão a posteriori. Não é preciso esperar uma nova eleição, por exemplo, para então pressionar os representantes sobre certas demandas ou punir aqueles que porventura agiram segundo interesses estritamente particulares. $\mathrm{O}$ que ainda parece distante é a elaboração de um conceito de soberania popular que leve em conta as contingências impostas pela passagem do tempo na origem da autoridade política.

É significativo que essas mudanças na ideia de povo, que trazem à tona os limites de uma visão demasiadamente unificadora e orientada por algo como a vontade geral, estejam essencialmente voltadas para a soberania do povo na forma do seu exercício. Só é possível revisar e repensar as práticas políticas de um povo que já está constituído. E, se dermos um passo adiante, talvez seja possível sugerir que ressignificar a soberania do povo para torná-la mais democrática passou necessariamente por criar e endossar formas indiretas do exercício do poder político. De fato, esse movimento, que multiplica as possibilidades de participação política e, ao mesmo tempo, contesta a possibilidade de um conteúdo 
substantivo estável para o bem comum, oferece uma solução viável e interessante da perspectiva democrática. Mas o que dizer do momento anterior, aquele em que o povo funda a comunidade política?

Boa parte da literatura que discute o tema da soberania de uma perspectiva democrática ocupa-se de repensar as possibilidades do exercício da soberania do povo. Ocorre que os esforços para democratizar o exercício da soberania popular, por meio do fomento a formas de participação diretas e indiretas, multilocalizadas e expandidas no tempo, tendem a deixar de lado a soberania do povo como a origem da autoridade política. Espejo (2011) é enfática em seu argumento de que o resgate das origens do poder político nos Estados modernos impõe um desafio democrático. Se até hoje a teoria política não lidou tão bem com o "paradoxo da autoconstituição do povo", talvez parte das razões esteja associada a um diálogo difícil entre a teoria democrática e outras abordagens que lidam com o tema da constituição da autoridade política.

Compartilhamos da crítica da autora que chama atenção para as dificuldades da teoria política contemporânea em lidar com o povo na forma de poder constituinte. O desconforto de Espejo com a unificação que marca a origem da autoridade pública decorre da sua interpretação como uma imagem do passado ou como uma visão do futuro. Nos dois casos, trata-se se de uma promessa que não se materializa em nenhum tempo ou espaço concreto, e não pode ser estabilizada. Quando não nos perguntamos quem é o povo capaz de legitimar a autoridade política perdemos de vista o caráter indeterminado dessa unificação, que supostamente ocorre porque há uma coincidência entre a razão e a vontade geral, que vemos clara na obra de Rousseau (Espejo, 2011, p. 5, p. 46).

Se para as democracias não basta que o povo seja a origem do poder político, também é verdade que teorias da 
soberania popular não explicam tão bem a origem democrática da autoridade. De acordo com Espejo - e com Daniel Lee, como vimos - o povo já existe antes da instituição dos processos democráticos (Espejo, 2011, p. 42). Enquanto Lee destaca que pressupor a existência do povo foi importante para constituir uma nova forma de autoridade política, Espejo insiste que não apenas o povo se define por critérios não democráticos, mas que não é possível apontar para a sua unificação em nenhum momento no tempo. Portanto, ainda que tenhamos bem estabelecidas as fronteiras do povo no espaço e no território, como é o caso dos Estados nacionais, não há como ver o povo de maneira estática e imutável. Ou seja, a definição demográfica de povo não abarca a sua dimensão política, principalmente se o povo, nesse sentido último, for entendido como um agente abstrato ou até uma ficção.

O problema é que definições de povo geralmente se referem ao exercício do poder político, e não se desdobram para a constituição do povo enquanto sujeito coletivo detentor da autoridade política última. De acordo com Espejo, esse povo que "já está lá” nas sociedades democráticas não pode ser fielmente retratado:

[...] todas as vezes que se tenta enquadrar uma multidão real de acordo com seu acordo político, é como se fosse escolhida uma fotografia estática de uma figura em movimento; o quadro engana porque a figura continua. (Espejo, 2011, p. 45, tradução nossa)

Nesse sentido, mesmo que o povo pareça unificado em um determinado momento, é muito difícil mostrar que o povo segue unificado ao longo do tempo. Quando se declara que todos os indivíduos consentiram, alguns deles já podem ter mudado de ideia (Espejo, 2011, p. 45). Isso também vale para princípios normativos que podem sustentar 
a ideia de uma unificação. Ainda que uma sociedade seja orientada por critérios normativos comuns, é fundamental entender que a interpretação desses critérios vai se transformar ao longo do tempo. Sabemos que as instituições políticas demoram a incorporar as mudanças, e esta é uma oportunidade para percebermos a distância entre interesses, desejos e crenças da população, e o modus-operandi e os objetivos das instituições - ainda que, muitas vezes, essa seja uma estratégia de proteção dos valores democráticos. Em resumo, não há como mostrar que o povo se unifica porque essa unificação requer uma abstração temporal, e o povo sempre existe no tempo - ele sempre muda (Espejo, 2011, p. 45).

E qual a saída sugerida pela autora para incorporar dimensões como o tempo e a contingência na própria noção de povo? Espejo vê a soberania popular como um processo cujo ponto de chegada está sempre em disputa - o povo é uma série de eventos que só é estável em sua autopercepção 50 no presente, mas totalmente aberto ao novo. Espejo acredita que só é possível sustentar a noção de vontade geral à medida que ela não representa um objetivo, mas pode ser determinada pelas expectativas dos vários indivíduos (Espejo, 2011, p. 13). As transformações às quais o povo está sempre sujeito são fonte de legitimidade democrática porque o povo não é mais entendido como um agregado de indivíduos, mas como uma série de eventos que se sucedem no tempo.

Recuperamos essa compreensão de Espejo de que o povo é um processo não para defendê-la, mas como uma inspiração para lidar com as tensões que marcam a soberania popular. Apresentá-la é uma maneira de argumentar que há boas razões para revisar a soberania popular e torná-la mais afeita às contingências da passagem do tempo - que transforma as pessoas, os contextos e as ideias políticas. Ora, muitos autores se esforçaram por fazer do exercício da soberania mais democrático, justamente incorporando formas de participação 
direta e indireta que são mais capazes de refletir a instabilidade dos consensos, o conflito e a passagem do tempo. É o caso de trabalhos como o de Carole Pateman (1970), Nadia Urbinati (2006), mas também de autores brasileiros como Adrian Gurza Lavalle e Ernesto Isunza Vera (2011) e Luis Felipe Miguel (2014). O que Espejo sugere é dar um passo além: a autora nos encoraja a repensar a noção de povo, na origem da autoridade política, como um conceito também contingente e aberto ao futuro.

\section{Considerações Finais}

Nosso percurso nos leva de volta a Rousseau. Certo da premência da participação do povo na constituição da pessoa pública do Estado, que - pelo pacto - " [...] produz um corpo moral e coletivo composto de tantos membros como são os votos da assembleia" (Rousseau, 2006, I, cap. 6, p. 22), o autor alerta que a vida e o movimento dessa comunidade dependem igualmente da atividade legislativa desse mesmo povo. É por isso que importa tanto enfatizar os riscos da ação do representante no modelo rousseauniano. São as assembleias periódicas que asseguram aos cidadãos a oportunidade de exercer seu papel de soberano, e corrigir qualquer desvio do governo em relação à vontade geral.

Também não surpreende que desde o início estejamos intrigadas com a maneira como Rousseau lida com a origem e o exercício soberania popular. $\mathrm{O}$ autor é enfático em recomendar atenção ao trabalho legislativo, que deve se orientar pela vontade geral e por isso mesmo precisa ser exercido pelo povo. Mas o genebrino reconhece que o povo nem sempre é capaz de tomar decisões que visam ao bem comum (Rousseau, 2006, II, cap. 6, p. 48) e daí a sua preocupação em assegurar que, reunido em assembleia, o povo esteja mais protegido da influência dos interesses particulares (Rousseau, 2006, IV, cap. 15, pp. 112-16). Se a vontade geral é absoluta e nunca erra, o mesmo não se pode dizer 
de todas as leis formuladas pelo povo - que são verdadeiras e incontroversas apenas se estão de acordo com o bem comum (Putterman, 2010, p. 24). Além disso, o autor é cuidadoso o suficiente para apontar que o governo instituído para executar as leis nas situações particulares pode ser, a qualquer momento, corrompido pela vontade individual. Daí, inclusive, a necessidade de reconhecer que o poder dos governantes e magistrados é limitado e controlado, uma vez que se trata de "[...] uma forma provisória que ele confere à administração, até quando lhe aprouver ordená-la de maneira diferente" (Rousseau, 2010, III, cap. 18, p. 120).

Mais uma vez, nos parece possível enxergar certos paralelos entre as inquietações desse autor do século XVIII e as preocupações da teoria democrática hoje. Não porque tenhamos encontrado as mesmas respostas - teorias da democracia deliberativa, por exemplo, destacam a importância de pluralizar e diversificar as formas de participação (indiretas, inclusive), para que diferentes experiências e realidades sejam consideradas no processo de tomada de decisão política (Habermas, 2014, Benhabib, 1996, Young, 2001, Fraser, 1990 etc.). Ainda assim, seguimos como Rousseau, desconfiadas dos governantes e reiterando o valor da participação. Nós, como ele, queremos aproximar, tanto quanto possível, a força da vontade do povo aos processos que movem as comunidades políticas, certos de que daí advém uma forma de legitimidade política e democrática. Ao mesmo tempo, é obscura a dimensão da vontade geral que marca o poder constituinte, que é absoluta, indivisível e inequívoca - mas será democrática? O próprio genebrino reconhece que o pacto social pode a qualquer momento ser rompido ou revogado:

[...] não há no Estado nenhuma lei fundamental que não se possa revogar, nem mesmo o pacto social; porque, se todos os cidadãos se reunissem para romper esse pacto de comum 
acordo, não há dúvida de que ele seria muito legitimamente rompido (Rousseau, 2006, III, cap. 18, p. 122).

Não é este o mesmo tipo de poder arbitrário ou extraconstitucional do povo que descreve Lee? Se o poder constituinte se define por essa autoridade ilimitada, então não é direta a sua relação com o poder constituído, constrangido pelo ordenamento legal e pelo arcabouço institucional de uma sociedade. Ainda assim, a legitimidade política das democracias de hoje depende de uma aproximação desses dois papéis exercidos pelo povo, ou seja, é preciso que haja alguma conexão entre a abstração coletiva da qual emana a autoridade e o sujeito coletivo e plural que a exerce. Aos dois chamamos povo, também por isso parece fazer sentido perguntar-nos sobre o desconforto que emerge quando se quer proteger o potencial democrático dessa forma de soberania. Se entendermos a soberania popular como um conceito chave para a legitimidade do poder político, então estamos diante de uma tensão insuperável entre um elemento simbólico (absoluto) e um elemento prático (democrático) da noção de povo.

\section{Gabriela Rodrigues da Guia Rosa}

Doutoranda e mestre em Ciência Política pela Universidade de São Paulo. São Paulo, SP, Brasil. Pesquisadora do grupo Soberania Popular em Perspectiva Histórica (DCP-USP) e editora da área de Teoria Política da Leviathan - Caderno de Pesquisa Política.

\section{Bibliografia}

ARENDT, Hannah. 2020. Sobre a Revolução. São Paulo: Companhia das Letras.

BENHABIB, Seyla. 1996. Toward a Deliberative Model of Democracy.

In: BENHABIB, Seyla. (ed.) Democracy and Difference: Contesting the

Boundaries of the Political. Princeton: Princeton University Press.

DAHL, Robert A. 2012. A democracia e seus críticos. São Paulo: WMF

Martins Fontes. 
DERATHÉ, Robert. 2009. Jean-Jacques Rousseau e a Ciência Política do seu Tempo. São Paulo: Barcarolla.

DUNN, John. 2019. Setting the People Free: The Story of Democracy. Princeton; Oxford: Princeton University Press.

ESPEJO, Paulina Ochoa. 2011. The time of Popular Sovereignty: Process and the Democratic State. Haverford: Penn State University.

FRASER, Nancy. 1990. Rethinking the Public Sphere: A Contribution to the Critique of Actually Existing Democracy. Social Text. n. 25/26. pp. 56-80. DOI: 10.2307/466240p.

HABERMAS, Jürgen. 2014. Prefácio de 1990. In: HABERMAS, Jürgen. Mudança estrutural da esfera pública: investigações sobre uma categoria da sociedade burguesa. São Paulo: Unesp.

HABERMAS, Jürgen. 2020 [1988]. Soberania popular como procedimento (1988). In: HABERMAS, Jürgen. Faticidade e Validade: Contribuições para uma teoria discursiva do direito da democracia.

São Paulo: Unesp.

GURZA LAVALLE, Adrian. ISUNZA VERA, Ernesto. 2011. A trama da crítica democrática: da participação à representação e accountability. Lua Nova. v. 84, pp. 95-139. DOI: 10.1590/S0102-64452011000300005 2011, vol. 84 .

KRITSCH, Raquel. 2011. Soberania, lei, vontade geral e autoridade legítima segundo Do Contrato Social de Jean-Jacques Rousseau. Revista Espaço Acadêmico. v. 10, n. 119, pp. 86-97. Disponível em: https://bit.ly/3ggvT5c. Acesso em: 19 ago. 2021.

LEE, Daniel. 2016. Popular Sovereignty in Early Modern Constitutional Thought. Oxford: Oxford University Press.

LEVITSKY, Steven; ZIBLATT, Daniel. 2018. Como as democracias morrem. Rio de Janeiro: Zahar.

MADISON, James; HAMILTON, Alexander; JAY, John. 1993. Os Artigos Federalistas 1787 - 1788. Rio de Janeiro: Nova Fronteira.

MANIN, Bernard. 1987. On Legitimacy and Political Deliberation. Political Theory. v. 15, n. 3, pp. 339-368. DOI: 10.1177/0090591787015003005

MIGUEL, Luis Felipe. 2014. Democracia e representação: territórios em disputa. São Paulo: Unesp.

NÄSSTRÖM, Sofia. 2007. The Legitimacy of the People. Political Theory. V. 35, n. 5, pp. 624-658. DOI: 10.1177/0090591707304951p.

NEVES, Rafael. 2017. Pensador republicano ou Nacionalista Revolucionário? Rousseau nas lentes de Schmitt e Arendt. Cadernos de Filosofia Alemã. v. 22, n. 3, pp. 77-89. DOI: 10.11606/issn.2318-9800. v22i3p77-89 
OSTRENSKY, Eunice. Soberania e Representação: Hobbes,

Parlamentaristas e Levellers. 2010. Lua Nova. v. 80, pp. 151-179.

DOI: $10.1590 /$ s0102-64452010000200007.

PATEMAN, Carole. 2012. Participatory Democracy Revisited. Perpectives on Politics. v. 10, n. 1, pp. 7-19. DOI: 10.1017/S1537592711004877p.

PATERMAN, Carole. 1970. Participation and democratic theory. Cambridge: Cambridge University Press.

PITKIN, Hanna F. 1967. The Concept of Representation. California: University of California Press.

PRZEWORSKI, Adam. 2020. Crises da Democracia. Rio de Janeiro: Zahar.

PUTTERMAN, Ethan. 2010. Rousseau, Law and the Sovereignty of the People. Cambridge: Cambridge University Press.

ROSANVALLON, Pierre. 2011. Democratic Legitimacy: Impartiality, Reflexivity, Proximity. Princeton; Oxford: Princeton University Press. ROSANVALLON, Pierre. 2008. Counter Democracy: Politics in an Age of Distrust. Nova York: Cambridge University Press.

ROSANVALLON, Pierre. 1998. El Pueblo Inalcanzable. Cidade do México: Instituto Mora.

ROUSSEAU, Jean-Jacques. 2006 [1762] O Contrato Social. São Paulo: Martins Fontes.

RUNCIMAN, David. 2019. How Democracy Ends. Londres: Profile Books.

SCHUMPETER, Joseph A. 2017. Capitalismo, Socialismo e Democracia.

São Paulo: Editora Unesp.

URBINATI, Nadia. 2006. Representative Democracy: Principles and Genealogy.

Chicago; London: The University of Chicago Press. 
"Do povo, para o povo e pelo povo" 


\section{"DO POVO, PARA O POVO E PELO POVO": ORIGEM E EXERCÍCIO DA SOBERANIA POPULAR NA TEORIA POLÍTICA CONTEMPORÂNEA}

\section{GABRIELA RODRIGUES DA GUIA ROSA}

Resumo: Este artigo aponta as influências do conceito de soberania popular formulado por Rousseau na teoria política contemporânea. Partindo da ideia de que democracia e soberania do povo não estão necessariamente vinculadas, pretendemos mostrar como essa sobreposição está fundamentada em uma concepção de povo próxima da formulação rousseauniana. Além disso, a distinção entre a origem e o exercício do poder político continua produzindo efeitos no modo como pensamos a democracia e a soberania do povo. Mostramos, então, que essa distinção afastou a teoria política das discussões sobre a democracia, a soberania e o poder constituinte do povo.

Palavras-chave: Soberania Popular; Democracia; Poder Constituinte; Rousseau.

\section{"OF THE PEOPLE, BY THE PEOPLE AND FOR THE PEOPLE": ORIGINS AND EXERCISE OF POPULAR SOVEREIGNTY IN CONTEMPORARY POLITICAL THEORY}

Abstract: This article highlights the influences of popular sovereignty as formulated by Rousseau to contemporary political theory. Based on the idea that democracy and popular sovereignty are not necessarily connected, we intend to show how such overlapping is rooted in conception of people inherited from the Rousseaunian ideals. Also, we highlight how the distinction between the origins and the actual exercise of political power still affects our thoughts on democracy and popular sovereignty. We argue that this distinction drove political theory away from 
Resumos |Abstracts

debates on democracy, sovereignty and the constituent power of the people.

Keywords: Popular Sovereignty; Democracy; Constituent Power; Rousseau.

Recebido: 29/07/2018 Aprovado: 29/07/2021 